\title{
A Rapid Assay for Peroxidase Activity
}

\author{
BY R. P. F. GREGORY* \\ Department of Biochemistry, University of Cambridge
}

(Received 23 March 1966)

\begin{abstract}
1. Peroxidase has been assayed by a chronometric method involving the coupled reaction of ascorbic acid with the product of the enzymic action on benzidine. 2. Measurements of the activities of horseradish and tea peroxidase by this and two other methods, involving respectively pyrogallol and o-dianisidine, are compared. 3. It is claimed that the chronometric method is relatively simple, rapid and accurate. 4. The method can be used in the presence of polyphenol oxidases.
\end{abstract}

During an extensive purification of the polyphenol oxidases in tea (Bendall \& Gregory, 1963; Gregory \& Bendall, 1966) a need arose for a method of measuring peroxidase activity that could be applied to the many fractions that were obtained during column chromatography. The main requirements for such a method are that it should be rapid and simple and that polyphenol oxidase should not interfere.

Maehly \& Chance (1954) give an extensive review and criticism of peroxidase assay methods including chronometric procedures. The classical method, in which pyrogallol is oxidized to purpurogallin, is laborious and is above all inapplicable to systems containing phenol oxidases. Since variations on this method are, however, still widely used, comparisons have been made between the present system and a purpurogallin method, by using the peroxidase from horseradish, which has no phenoloxidase activity. Comparison has also been made with an assay involving the oxidation of $o$-dianisidine.

\section{EXPERIMENTAL}

Materials. Horseradish peroxidase was prepared according to the method of Kenten \& Mann (1954) up to the first ethanol fractionation. The $E_{405} / E_{275}$ ratio was $1 \cdot 11$, and the Purpurogallinzahl, estimated by the method of Lemberg \& Legge (1949), was 210. The sample from tea was obtained during the preparation of polyphenol oxidase from the fresh shoots by the method of Gregory \& Bendall (1966). It was the fraction, containing peroxidase, that was separated from the bulk of the polyphenol oxidase at stage VI. It showed appreciable polyphenol-oxidase activity. All reagents were of analytical grade, apart from L-ascorbic acid (Roche Products Ltd., Welwyn Garden City, Herts.), benzidine (crude, for blood test) and o-dianisidine (British Drug Houses Ltd., Poole, Dorset). Glassware was freed

* Present address: Department of Biological Chemistry, University of Manchester. from metallic contaminants by washing with $\mathrm{HNO}_{3}$ and twice-distilled water was used.

Reagents. The following reagents were used: (i) a suspension freshly prepared by adding $2 \mathrm{ml}$. of a saturated solution of benzidine in ethanol to $98 \mathrm{ml}$. of $0.1 \mathrm{M}$-sodium citrate buffer, pH5.3; (ii) a standard solution of 1-5 mMascorbic acid; (iii) $0 \cdot 20 \mathrm{M}-\mathrm{H}_{2} \mathrm{O}_{2}$.

Method. The reaction was carried out at $22^{\circ}$. Measured portions of each reagent $(1 \mathrm{ml}$.) were mixed in the order given in a test tube. Without loss of time a sample of enzyme $(0 \cdot 01-0.1 \mathrm{ml}$.) was injected from a constriction pipette, and a stopclock was started simultaneously. The tube contents were well mixed. A sudden development of blue colour indicated the complete oxidation of the ascorbic acid and the time required for the appearance of the colour was recorded. The unit of activity is expressed as $\mu$ moles of ascorbic acid oxidized/min.

\section{RESULTS AND DISCUSSION}

Notes on the procedure. (1) Benzidine is a carcinogen, and precautions must be taken to avoid contact with it. It was not necessary to recrystallize the sample. (2) By using a suspension, the benzidine is maintained at a fixed concentration, allowing the test volume to be varied with little affect on accuracy. (3) The rate of oxidation of ascorbic acid is less than $1 \%$ of the benzidine-coupled reaction rate. (4) The mean variation of the times recorded for replicate measurements is about 1-2 sec. for reaction times up to $2 \mathrm{~min}$. (5) The given concentration of hydrogen peroxide is optimum for both the horseradish and the tea enzyme. (6) The time taken for the blue colour to appear is inversely proportional to the quantity of enzyme, proportional to the quantity of ascorbic acid and is not affected within the experimental error given by changes of up to $10 \%$ in either the quantity of benzidine suspension, the final volume, or the hydrogen peroxide concentration. (7) $\mathrm{A} \mathrm{pH}$ value of $5 \cdot 3$ is optimum for each enzyme. 


\section{Table 1. Activities of two peroxidase preparations by three methods}

The methods used were: (i) the Polis \& Shmukler (1953) method; (ii) the Worthington \& Teller method (see the text); (iii) The system described in the present paper. Activities of the horseradish enzyme are expressed per mg. of enzyme; activities of the tea enzyme are expressed per ml. of enzyme preparation.

$\begin{array}{cccc}\text { Method... } & \text { (i) } & \text { (ii) } & \text { (iii) } \\ \text { Substrate... } & \text { Pyrogallol } & o \text {-Dianisidine } & \text { Benzidine } \\ \text { Units... } & \mu \text { moles of } & \mu \text { moles of } & \mu \text { moles of } \\ & \text { purpurogallin } / \mathrm{min} . & \mathrm{H}_{2} \mathrm{O}_{2} / \mathrm{min} . & \text { ascorbate } / \mathrm{min} . \\ & 1070 & 566 & 3700 \\ & - & 14 & 184\end{array}$

Interfering substances. Haemoglobin, cytochrome $c$ and $\mathrm{Cu}^{2+}$ caused a dull blue colour to appear, slowly, but only when they were present in such concentrations that they could easily be recognized by their colour. Catalase and cytochrome $f$, which has catalase activity (Forti, Bertolè \& Zanetti, 1965), caused no alteration in recorded times up to the point where the effervescence became unmanageable. Tea polyphenol oxidase added to either preparation caused no change in measured activities.

Comparison with other methods. In Table 1 are given values obtained for the activities of the tea and horseradish peroxidase preparations by using the above method and two others: a method based on the oxidation of pyrogallol (Polis \& Shmukler, 1953), and one in which the progress of the oxidation of 0 -dianisidine is followed directly in a spectrophotometer. The last method was developed by C. S. Worthington \& J. D. Teller and appears in catalogues of the Worthington Biochemical Corp., Freehold, N.J., U.S.A., from 1959 onwards. The ratios of activities of the two enzyme preparations measured by the o-dianisidine method and by the present procedure differ twofold. This is regarded as an indication of a difference in substrate specificity.

This work was supported by the Tea Association of Central Africa, the Tea Research Institute of East Africa and the Agricultural Research Council. Thanks are due to Dr D. S. Bendall and Professor F. G. Young, F.R.S., for their interest in this work, and to Dr C. V. Cutting for supplying tea leaf material.

\section{REFERENCES}

Bendall, D. S. \& Gregory, R. P. F. (1963). In Enzyme Chemistry of Phenolic Compounds, p. 7. Ed. by Pridham, J. B. Oxford: Pergamon Press Ltd.

Forti, G., Bertolè, M. L. \& Zanetti, G. (1965). Biochim. biophys. Acta, 109, 33.

Gregory, R. P. F. \& Bendall, D. S. (1966). Biochem. J. 101,569 .

Kenten, R. H. \& Mann, P. J. G. (1954). Biochem.J. 57, 347.

Lemberg, R. \& Legge, J. W. (1949). Hematin Compounds and Bile Pigments, p. 422. Now York: Interscience Publishers Inc.

Maohly, A. C. \& Chance, B. (1954). Meth. biochem. Anal. 1, 357.

Polis, B. D. \& Shmukler, H. W. (1953). J. biol. Chem. 201, 475. 